American Journal of Immunology 6 (2): 15-19, 2010

ISSN 1553-619X

(C) 2010 Science Publications

\title{
Antibiotic Susceptibility and Immunomodulatory Potential of Chosen Bacterial Pathogens
}

\author{
${ }^{1}$ M. Sujatha, ${ }^{2} \mathrm{P}$. Dhasarathan and ${ }^{3} \mathrm{~B}$. Karthick \\ ${ }^{1}$ Research and Development Centre, Bharathiyar University, \\ Coimbatore, 641 046, India \\ ${ }^{2}$ Department of Biotechnology, Prathyusha Institute of Technology and Management, \\ Thiruvallur-602 025, India \\ ${ }^{3}$ Department of Biotechnology, Sri Kaliswari College, Sivakasi-626 130, India
}

\begin{abstract}
Problem statement: Antibiotic susceptibility is still the best way for bacterial pathogen escape mechanism against immunity. Approach: In the present investigation, bacterial pathogens like Staphylococcus aureus, Escherichia coli, Aeromonas hydrophila, Klebsiella and Pseudomonas aeruginosa were used to screen antibiotic susceptibility and immunomodulatory potential. Results: All the test pathogens were sensitive to all the test antibiotics $11 \pm 2 \mathrm{~mm}$ ) except penicillin. The conditions for the preparation of antigens of intact natural composition and conformation from pathogens (whole cell and heat killed), were determined using Swiss albino mice (Balb/C) as experimental species. Immunomodulatory potential of test pathogens were screened using animal model. Test pathogen decreases the body weight comparing that of normal mice, some notable changes were also noted in activity, growth, water consumption, feed consumption. Antibody titre level in animal serum decreased upto 50\% in whole cell pathogen and heat killed pathogen treated animals. Conclusion: The five pathogens administered animals, decrement in B-lymphocyte was much pronounced in Pseudomonas aeruginosa followed by Escherichia coli, Staphylococcus aureus, Klebsiella sp., Aeromonas hydrophila in the 5 week. Pathogen treated mice showed an IgG suppressive effect. It is found to be suppressive to $\mathrm{T}$ cell production, so induction in cell mediated immunity has confirmed pathogenic potential of test pathogens. All these test pathogenic strains were remarkably suppressing immune system of pathogen exposed animals.
\end{abstract}

Key words: Bacterial pathogens, immune response, antibiotic susceptibility, immunomodulatory, mice

\section{INTRODUCTION}

Pathogens expresses many potential virulence factors such as, surface proteins that promote colonization of host tissues; invasins that promote bacterial spread in tissues (leukocidin, kinases, hyaluronidase); surface factors that inhibit phagocytic engulfment (capsule, Protein A); biochemical properties that enhance their survival in phagocytes (carotenoids, catalase production); immunological disguises (Protein A, coagulase, clotting factor) and membrane-damaging toxins that lyse eukaryotic cell membranes (hemolysins, leukotoxin, leukocidin; exotoxins that damage host tissues or otherwise provoke symptoms of disease (TSST, ET) and inherent and acquired resistance to antimicrobial agents (Lowy, 1998; Akond et al., 2009; Maripandi and Al-Salamah, 2010).
For the majority of diseases caused by bacterial pathogens, pathogenesis is multifactorial, so it is difficult to determine precisely the role of any given factor. However, there are correlations between strains isolated from particular diseases and expression of particular virulence determinants, which suggests their role in particular diseases (Shokrollah et al., 2009).

A better understanding of the relationship between immune responses to specific pathogens and protection is needed. This information will be required as vaccines move toward licensure. For example, what comprises a surrogate marker for protection? Is a calculated protective antibody level a reasonable surrogate marker for protection and equivalency measure in other populations than the one in which an efficacy trial was run? Perhaps in vitro functional equivalency could be used to make the case of antibody levels equivalency more acceptable as a surrogate marker (Lowy, 1998). In

Corresponding Author: P. Dhasarathan, Department of Biotechnology, Prathyusha Institute of Technology and Management, Thiruvallur-602 025, India 
vivo protection studies in animals may be able to help interpret the significance of antibody responses. A difficulty here is the need for an animal model which closely mimics the population expected to develop an infection. In an immunological survey of bacterial pathogenic antigens, display libraries with polypeptides fused to bacterial surface proteins (Dhasarathan et al., 2010). Hence, in the present investigation planned to screen the antibiotic susceptibility and immunomodulatory potential of chosen bacterial pathogens.

\section{MATERIALS AND METHODS}

Antibiotic susceptibility test: The chosen pathogenic strains (Staphylococcus aureus, Escherichia coli, Aeromonas hydrophila, Klebsiella and Pseudomonas aeruginosa) were tested for the sensitivity to antibiotics by the disc diffusion method. The test organism, 12-24 h culture was spread uniformly on the surface of the sterile air dried Muller-Hinton agar plated using sterile cotton swabs. The selected antibiotic (Penicillin (10 $\mu \mathrm{g})$, Chlorampenicol (5 $\mu \mathrm{g})$, Streptomycin $(5 \mu \mathrm{g})$, Erythromycin $(5 \mu \mathrm{g}))$ discs were placed on the centre of the test culture seeded plates using sterile forceps. Each antibiotic control, culture control and media control plates were maintained. The plates were incubated at $37^{\circ} \mathrm{C}$ for $24 \mathrm{~h}$ and measured the susceptibility of test strain was classified as being Sensitivity (S), Intermediate (I) or Resistance (R).

Immunological study: The five bacterial pathogens were collected from Microbial Type Culture Collection (MTCC) Institute of Microbial Technology (IMTECH) Chandigarh India. The samples were brought out the laboratory immediately and checked for their viability and culture were streaked on Muller-Hinton agar slants for storage and sub cultured on Muller-Hinton broth for analysis. The test strains were prepared into two different types of antigens like that heat killed bacterial antigens and whole cell bacterial antigens.

Preparation of heat killed antigen: Approximately $2.5 \times 10^{5}$ cells $\mathrm{mL}^{-1}$ test strains were heat killed at $60^{\circ} \mathrm{C}$ for $1 \mathrm{~h}$ in a water bath and centrifuged at $3000 \mathrm{rpm}$ for $15 \mathrm{~min}$. The pellet was washed with PBS for purity and resuspended into PBS and make into desired concentration.

Preparation of whole cell bacterial antigen: The test strain was centrifuged at $3000 \mathrm{rpm}$ for $30 \mathrm{~min}$, pellet washed with PBS and then packed cells were resuspended to desire concentration $\left(2.5 \times 10^{5}\right.$ cells $\mathrm{mL}^{-1}$ for five different bacterial antigens) in PBS after counting in haemocytometer.

Animals and treatment: For the experimental study, mice weighing $(20 \pm 28 \mathrm{~g})$ were recruited from the acclimatized stock. Each group has 6 animals, housed in a specially designed cage with provision for systematic supply of pellets and water ad libitum. Test bacterial antigens were administered to the test animal and findout $\mathrm{LD}_{50}$ by method described by Dhasarathan et al. (2010). From $\mathrm{LD}_{50} 1 / 10^{\text {th }}$ concentration was determined and injected into test animal through intraperitonial route with primary dose $\left(2.5 \times 10^{5}\right.$ cell $\left.\mathrm{mL}^{-1}\right)$ and secondary doses $\left(5 \times 10^{5}\right.$ cell $\left.\mathrm{mL}^{-1}\right)$ after successive 3 days. After treatment, Food consumption, general conditions and other symptoms were observed daily and body weights were recorded during experimental period. Blood samples were collected after antigen treatment on the 1st, 2nd and 3rd weeks of test animals by cardiac puncture. The serum was separated for each group separately and kept on $-20^{\circ} \mathrm{C}$ till analysis. Heparin was used in collecting whole blood and leucocytes rich plasma for lymphocyte subset enumeration.

Screening of antibody titre: From the normal and treated mice, serum samples were used to screen the antibody levels. Quantification of serum antibodies were carried out by antibody titre plate technique containing respective antigens. $25 \mu \mathrm{L}$ of physiological saline was added in to the first well of microtitre plate, then $25 \mu \mathrm{L}$ of antiserum added in the first well of microtitre plate, the antiserum was serially diluted in the well of the row till the 11th well of the microtitre plate leaving the 12 th well as positive control. Then 25 $\mu \mathrm{L}$ of $1 \%$ test antigen in saline were added to all the wells of the microtitre plate. The plate was hand shaken for the effective mixing of reagents and incubated for an hour at $37^{\circ} \mathrm{C}$. After incubation period antibody titre was calculated based on the button formation in titre plate.

Enumeration of lymphocyte subset population: Five $\mathrm{ml}$ of blood samples were collected from test antigen treated and control mice using heparin pretreated vials. Lymphocytes were isolated using lymph prep solution and separated by Nylon wool column method described by (Dhasarathan et al., 2010). The separated subsets of lymphocytes were observed and enumerated by e rosette assay techniques (Dhasarathan et al., 2010).

Quantification of immunoglobulin: From the whole blood of normal and test animal, immunoglobulin was 
separated using protease 'A' column. The eluted immunoglobulin was read at $280 \mathrm{~nm}$. At $280 \mathrm{~nm}$ an absorbance of 1.0 is equivalent to an immunoglobulin concentration of $0.74 \mathrm{mg} \mathrm{mL}^{-1}$ which can calculate by this equation of:

\section{Absorbance at $280 \mathrm{~nm}$ of sample $\times$ range of blank $\times$ number of dilution factor to be used}

From the above equation the range of blank for immunoglobulin was consider as the constant (0.74).

\section{RESULTS}

In the present investigation, all the test pathogens were sensitive to all the test antibiotics, except penicillin (Table 1).

Evaluation of sub lethal concentration: One future which is common to several of the routine laboratory test on animal toxicity is the continuous use of pathogens to test animals and the point of death or the end of the test period occurs first four days (usually 96 h).The most widely adopted measure of test sample sufficient to kill $50 \%$ of test animal within specific period. The lethal concentration of test pathogens were found Staphylococcus aureus was $3.1 \times 10^{5}$ (cells $\mathrm{mL}^{-1}$ ), Escherichia coli was $6.4 \times 10^{5}$ (cells $\mathrm{mL}^{-1}$ ), Pseudomonas aeruginosa was $6.4 \times 10^{5}$ (cells $\mathrm{mL}^{-1}$ ) and Klebsiella sp. was $6.4 \times 10^{5}$ (cells $\mathrm{mL}^{-1}$ ).

Morphological analysis of normal and pathogen treated mice: Pathogens were adversely affect the animal growth, water consumption and feed consumption. This shows that pathogen decreases the body weight comparing that of normal mice, some notable changes were also noted in activity, growth, water consumption, feed consumption. It concludes, the pathogenic organism acts as biotic stress to the host animals (Table 2).

Screening of antibodies: An estimation of antibody levels in the serum after an antigenic challenge will expose the functioning of humoral immune system. In the present study, whole cell pathogen and heat killed pathogen treated mice blood samples were showed antibody suppressive effect (Table 3).

Table 1: Antibiotic susceptibility pattern of test pathogens against test antibiotics

\begin{tabular}{llcccc}
\hline & & \multicolumn{2}{c}{ Zone of inhibition $(\mathrm{mm})$ against test pathogens } \\
Antibiotic & Disc concentration $(\mu \mathrm{g})$ & S. aureus & E. coli & P. aeruginosa & A. hydrophila \\
\hline Penicillin & 10 & 0 & 0 & 0 & 0 \\
Chlorampenicol & 5 & 11 & 14 & 13 & 6 \\
Streptomycin & 5 & 8 & 12 & 12 & 9 \\
Erythromycin & 5 & 15 & 6 & 17 & 6 \\
\hline
\end{tabular}

Table 2: Morphological changes in normal animal and animals administered with different bacterial antigens

\begin{tabular}{|c|c|c|c|c|c|}
\hline Test organism & Test Ag & $\begin{array}{l}\text { Wt. of } \\
\text { animal }(g)\end{array}$ & $\begin{array}{l}\text { Movement of } \\
\text { the animal }\end{array}$ & $\begin{array}{l}\text { Water consumption } \\
\left(\mathrm{mL} \mathrm{day}^{-1}\right)\end{array}$ & $\begin{array}{l}\text { Feed consumption } \\
\left(\mathrm{g} \mathrm{day}^{-1}\right)\end{array}$ \\
\hline Normal & - & 25 & Normal & 30.00 & 35.0 \\
\hline \multirow[t]{2}{*}{ S. aureus } & \multirow[t]{2}{*}{ Heat killed and whole cell Ag } & 20 & Resting & 22.10 & 24.1 \\
\hline & & 21 & Abnormal & 22.07 & 27.3 \\
\hline \multirow[t]{2}{*}{ E. coli } & \multirow[t]{2}{*}{ Heat killed and whole cell Ag } & 20 & Abnormal & 20.00 & 27.6 \\
\hline & & 22 & Abnormal & 19.00 & 24.0 \\
\hline \multirow[t]{2}{*}{ P. aeruginosa } & \multirow[t]{2}{*}{ Heat killed and whole cell Ag } & 20 & Abnormal & 9.00 & 9.0 \\
\hline & & 22 & Abnormal & 10.00 & 12.6 \\
\hline \multirow[t]{2}{*}{ A. hydrophila } & \multirow[t]{2}{*}{ Heat killed and whole cell Ag } & 25 & Restless & 19.00 & 32.6 \\
\hline & & 23 & Resting & 18.00 & 29.3 \\
\hline \multirow[t]{2}{*}{ Klebsiella sp. } & \multirow[t]{2}{*}{ Heat killed and whole cell $\mathrm{Ag}$} & 28 & Abnormal & 12.07 & 24.0 \\
\hline & & 27 & Wound formation & 14.08 & 22.3 \\
\hline
\end{tabular}

Table 3: Estimation antibody titre in control and animals exposed with different types of test antigens

\begin{tabular}{|c|c|c|c|c|c|c|}
\hline Test antigen & Normal & S. aureus & E. coli & P. aeruginosa & A. hydrophila & Klebsiella \\
\hline \multicolumn{7}{|c|}{ Heat killed antigen } \\
\hline 1st week & $8 \log _{2}^{2}$ & $5 \log _{2}^{2}$ & $4 \log _{2}^{2}$ & $4 \log _{2}^{2}$ & $7 \log _{2}^{2}$ & $4 \log _{2}^{2}$ \\
\hline 2nd week & $9 \log _{2}^{2}$ & $4 \log _{2}^{2}$ & $5 \log _{2}^{2}$ & $5 \log _{2}^{2}$ & $7 \log _{2}^{2}$ & $5 \log _{2}^{2}$ \\
\hline 3rd week & $8 \log _{2}^{2}$ & $3 \log _{2}^{2}$ & $4 \log _{2}^{2}$ & $4 \log _{2}^{2}$ & $7 \log _{2}^{2}$ & $4 \log _{2}^{2}$ \\
\hline \multicolumn{7}{|c|}{ Whole cell antigen } \\
\hline 1st week & $8 \log _{2}^{2}$ & $7 \log _{2}^{2}$ & $5 \log _{2}^{2}$ & $5 \log _{2}^{2}$ & $6 \log _{2}^{2}$ & $4 \log _{2}^{2}$ \\
\hline 2nd week & $8 \log _{2}^{2}$ & $5 \log _{2}^{2}$ & $6 \log _{2}^{2}$ & $6 \log _{2}^{2}$ & $7 \log _{2}^{2}$ & $4 \log _{2}^{2}$ \\
\hline 3rd week & $8 \log _{2}^{2}$ & $4 \log _{2}^{2}$ & $4 \log _{2}^{2}$ & $4 \log _{2}^{2}$ & $6 \log _{2}^{2}$ & $3 \log _{2}^{2}$ \\
\hline
\end{tabular}


Am. J. Immunol., 6 (2): 15-19, 2010

Table 4: Estimation of B lymphocytes in animals administered with test antigens

\begin{tabular}{|c|c|c|c|c|c|c|}
\hline \multirow[b]{2}{*}{ Duration } & \multicolumn{6}{|c|}{ B-cells (\%)-test antigens } \\
\hline & Normal & S. aureus & E. coli & P. aeruginosa & A. hydrophila & Klebsiella sp. \\
\hline \multicolumn{7}{|c|}{ Heat killed bacterial antigen } \\
\hline 1st week & 33.3 & 23.9 & 23.5 & 20.4 & 28.3 & 27.5 \\
\hline 2nd week & 31.9 & 28.7 & 29.8 & 24.6 & 30.8 & 29.9 \\
\hline 3rd week & 32.8 & 29.9 & 22.6 & 22.7 & 24.5 & 23.9 \\
\hline \multicolumn{7}{|c|}{ Whole cell Bacterial antigen } \\
\hline 1st week & 32.2 & 23.7 & 23.1 & 20.1 & 28.0 & 27.2 \\
\hline 2nd week & 31.7 & 28.1 & 29.6 & 24.3 & 30.7 & 29.9 \\
\hline 3 rd week & 32.3 & 29.8 & 22.4 & 22.3 & 24.4 & 23.8 \\
\hline
\end{tabular}

Table 5: Isolation of Immunoglobulin ( $\mathrm{IgG})$ in normal and antigen exposed animal serum samples

\begin{tabular}{|c|c|c|c|c|c|c|}
\hline \multirow[b]{2}{*}{ Test antigen } & \multicolumn{6}{|c|}{ Concentration of immunoglobulin $\left(\mathrm{mg} \mathrm{mL}^{-1}\right)$} \\
\hline & Normal & S. aureus & E. coli & P. aeruginosa & A. hydrophila & Klebsiella sp. \\
\hline Heat killed Ag & 0.86 & 0.25 & 0.40 & 0.27 & 0.59 & 0.30 \\
\hline Whole cell Ag & 0.86 & 0.16 & 0.29 & 0.18 & 0.40 & 0.24 \\
\hline
\end{tabular}

Table 6: Estimation of T lymphocytes in animals administered with test antigens

\begin{tabular}{|c|c|c|c|c|c|c|}
\hline \multirow[b]{2}{*}{ Duration } & \multicolumn{6}{|c|}{ T-cells (\%)-test antigens } \\
\hline & Normal & S. aureus & E. coli & P. aeruginosa & A. hydrophila & Klebsiella sp. \\
\hline \multicolumn{7}{|c|}{ Heat killed bacterial antigen } \\
\hline 1st week & 62.2 & 36.8 & 35.3 & 34.4 & 40.1 & 36.8 \\
\hline 2nd week & 61.7 & 37.8 & 37.2 & 36.5 & 45.4 & 38.9 \\
\hline 3rd week & 63.8 & 36.3 & 36.1 & 32.4 & 32.1 & 37.6 \\
\hline \multicolumn{7}{|c|}{ Whole cell Bacterial antigen } \\
\hline 1st week & 62.2 & 33.7 & 34.3 & 32.2 & 38.1 & 36.7 \\
\hline 2nd week & 61.7 & 35.3 & 38.7 & 33.8 & 41.0 & 39.1 \\
\hline 3rd week & 63.8 & 34.4 & 36.3 & 31.2 & 35.3 & 38.3 \\
\hline
\end{tabular}

B-lymphocyte estimation: B-Lymphocyte counts using rosette forming assay revealed significant decrement in pathogens exposed mice than control (Table 4).

Purification of Immunoglobulin: An estimation of antibody level in the serum after an antigen challenge in expose the functioning of hummoral immune system. In the present study, pathogen treated mice showed an IgG suppressive effect. Pathogen treated mice showed moderate change in IgG production (Table 5).

T-Lymphocyte estimation: T-cell is a vital component in cell mediated immune response, gets suppressed due to exposure of antigen (whole cell and heat killed antigen). It is found to be suppressive to $\mathrm{T}$ cell production, so induction in cell mediated immunity has confirmed pathogenic potential of Pseudomonas aeruginosa and Staphylococcus aureus, E. coil, Aeromonas hydrophila and Klebsiella sp. (Table 6).

\section{DISCUSSION}

Cukrowska et al. (1996) stated the damage to spleenic Ig secreting cell reduces antibody production in mice administered with foreign particles. The inhibition of complement protein in antigenic challenge animal serum was observed (Karami et al., 2009). Dhasarathan et al. (2010) found that DNA molecule damage was occurred in animal administered with organochlorine pesticide. DNA molecule damage interferes with the protein synthetic machinery, which then reduces the production of antibody. A similar observation was made in the present study too. The suppression of antibody reflects on the reduction of humoral immuno response and this state subject the mice to easy infection.

Of the five pathogens administered animals, decrement in B-lymphocyte was much pronounced in Pseudomonas aeruginosa followed by Escherichia coli, Staphylococcus aureus, Klebsiella sp., Aeromonas hydrophila in the first week and compared to control, Staphylococcus aureus pathogen had more or less similar B-cell estimations in 3rd week. In present study, clearly confirm the decrement in B-cell number in mouse exposed to whole and heat killed pathogens. So the impact of whole cell and heat killed pathogenic molecules on the synthesis, proliferation and activation of lymphocytes. Gebel et al. (1997) and Dhasarathan et al. (2010) reported the differentiation of B-counts affected 
by pathogens. Muller et al. (1997) had reported that the immuno suppressive drug inhibits cell proliferation and T-cell cytotoxicity.

Here, it is remarkably noted that enhancement in $t$ and B-cell production due to immune complex of antigens. The enhancement of this type of immune responses confirms the potential of immune complexes to be used as vaccines. Several workers Genestier et al. (1998) and Dhasarathan et al. (2010) reported that immuno enhancive drugs enrich cell proliferation. Bcell proliferations modification depends on the exposure of antigens.

\section{CONCLUSION}

In the present investigation, heat killed bacterial antigen and whole cell bacterial antigen were tested for immunomodulation. The induction of immune cells against the optimal concentration of Staphylococcus aureus, Escherichia coli, Pseudomonas aeruginosa, Aeromonas hydrophila and Klebsiella sp. were confirmed by comparing with the several immunological assays in the normal mice. Immunomodulation to immune system was accessed directly by quantifying immunological factors that governs cell mediated and humoral immune response. All these test pathogenic strains were remarkably suppressing immune system of exposed animals.

\section{REFERENCES}

Akond, M.A., S.M.R. Hassan, S. Alam and M. Shirin, 2009. Antibiotic resistance of Escherichia coli isolated from poultry and poultry environment of Bangladesh. Am. J. Environ. Sci., 5: 47-52. DOI: 10.3844/.2009.47.52

Cukrowska, B., J. Sinkora, L. Mandel, I. Splichal and A.T.J. Bianchi et al., 1996. Thymic B cells of pig fetuses and germ-free pigs spontaneously produce IgM, IgG and IgA detection by ELISPOT method. Immunology, 87: 487-492. DOI: 10.1046/j.13652567.1996.499573.x
Dhasarathan, P., S. Saravanan and A. Perianayagasamy, 2010. Disease management by vaccination using Escherichia coli antigens. Afr. J. Pharm. Pharmacol., 4: 119-122. http://www.academicjournals.org/AJPP/PDF/pdf20 10/March/Dhasarathan\%20et\%20al.pdf

Gebel, T., S. Kevekordes, K. Par, R. Edenharder and H. Dunkelberg, 1997. In vivo genotoxicity of selected herbicides in the mouse bone-marrow micronucleus test. Arch. Toxicol., 71: 193-197. DOI: $10.1007 / \mathrm{s} 002040050375$

Genestier, L., R. Paillot, S. Fournel, C. Ferraro and P. Miossec et al., 1998. Immunosuppressive properties of methotrexate: Apotosis and clonal deletion of activated peripheral $\mathrm{T}$ cells. J. Clin. Invest., 102: 322-328. DOI: 10.1172/JCI2676

Karami, A., Z.A.M. Ahmad and K. Sijam, 2009. Morphological characteristics and pathogenicity of Synchytrium psophocarpi (Rac.) Baumann associated with false rust on winged bean. Am. J. Applied Sci., 6: 1876-1879. DOI: 10.3844/.2009.1876.1879

Lowy, F.D., 1998. Staphylococcus aureus infections. N. Engl. J. Med., 339: 520-532. DOI: 10.1056/NEJM199808203390806

Maripandi, A. and A.A. Al-Salamah, 2010. Analysis of Salmonella enteritidis outer membranbe proteins and lipopolysacharide profiles with the detection of immune dominant proteins. Am. J. Immunol., 6: 1-6. DOI: 10.3844/.2010.1.6

Muller, M., S. Strand, H. Hug, E.M. Heinemann and H. Walczak et al., 1997. Drug-induced apotosis in hepatoma cells in mediated by the $\mathrm{CD}_{95}$ (APO$1 / \mathrm{Fas}$ ) receptor/legend system and involves activation of wild type p53. J. Clin. Invest., 99: 403-413. DOI: 10.1172/JCI119174

Shokrollah, H., T.L. Abdullah, K. Sijam and S.N.A. Abdullah, 2009. Determination of the presence of huanglongbing in seeds and movement of the pathogen in citrus reticulate. Am. J. Applied Sci., 6: 1180-1185. DOI: 10.3844/.2009.1180.1185 